\title{
Transmembrane Protein 65
}

National Cancer Institute

\section{Source}

National Cancer Institute. Transmembrane Protein 65. NCl Thesaurus. Code C158553.

Transmembrane protein 65 (240 aa, $26 \mathrm{kDa}$ ) is encoded by the human TMEM65 gene.

This protein plays a role in heart development and localization of gap junction proteins and mitochondria. 